\title{
Uwagi na marginesie lektury literackich kontestacji Dubravki Ugrešić
}

\begin{abstract}
Czapik-Lityńska Barbara, Uwagi na marginesie lektury literackich kontestacji Dubravki Ugrešić (Parenthetical Remarks on Literary Contestations by Dubravka Ugrešić). „Poznańskie Studia Slawistyczne" 6. Poznań 2014. Publishing House Science and Innovate, pp. 49-62. ISBN 978-83-63795-51-1. ISSN 2084-3011.

In the article, the literary texts of the Croatian authoress are considered, since they present a critical comportment that is to remain in opposition to the crisis of the contemporary culture. The article makes an attempt to describe a specificity of the writer's literary contestations, derived from a stance of the avant-garde and modern rebellion, adopted among others by Miroslav Krleža, and from an intellectual revolt, expressed by the postmodern aesthetics and philosophy. The growing on both contestation traditions determines a manner of thinking, perceptiveness of interpretation regarding the depicted world and life. The literary contestations of Ugrešic focus on problems of the postmodern aesthetics, ethics, sociopolitical and cultural transformations.
\end{abstract}

Keywords: Dubravka Ugrešić; literary contestation; Miroslav Krleža; intellectual revolt; postmodern aesthetics

Braterska przyjaźń przenosi góry! Tak zapewnia mój elementarz.

D. Ugrešić, Kultura klamstwa

Chorwacka pisarka Dubravka Ugrešić należy do najbardziej krytycznych autorek współczesnych i do najbardziej przenikliwych krytyczek kultury. Indywidualna, podmiotowa postawa, zaangażowanie intelektualne w skomplikowane problemy społeczno-kulturowe czyni z niej oryginalną postać czasów ponowoczesnych. W swojej ojczyźnie jest uważana za osobę kontrowersyjną, za outsiderkę ${ }^{1}$ Jej poglądy nie znalazły zrozumienia wśród Chorwatów, którzy nie zaakceptowali antynacjonalistycznej i antywojennej

1 Pisarka w każdej niemal książce utożsamia się z rolą „zaprzysięgłej outsiderki” (e.g. Ugrešić 2001: 102). 
krytyki, zarzucając autorce: jątrzenie, projugosłowiańskość, naiwność, niezrozumienie aktualnej sytuacji politycznej, jugonostalgię (Biti 2005), a nawet brak patriotyzmu (Jelčić 1997)². Nieprzychylność środowiska przyczyniła się do opuszczenia kraju. Od wyjazdu Dubravki Ugrešić minęło wiele lat i dzisiaj na większość skomplikowanych problemów i sytuacji zostało rzucone nowe światło. Dystans czasowy złagodził zarówno opinie Chorwatów, jak i samej pisarki. Szkoda, że jej dorobek nie jest doceniony, gdyż twórczość pisarki zasługuje na najwyższe uznanie. Wyróżnia ją mistrzowski artyzm i wysoka świadomość najbardziej istotnych problemów współczesnej kultury. Podejmując je, autorka wpisuje się w analityczne doświadczenia hermeneutyki, służące rozumieniu literatury i kultury, człowieka i społeczeństwa ${ }^{3}$. Jako pisarka ponowoczesności korzysta z wielu literackich strategii wspomagających semantyczne prowokacje do myślenia.

Twórczość Dubravki Ugrešić jest w Polsce dobrze znana, lubiana i ceniona. Moje uwagi odnoszę do tekstów thumaczonych na język polski i powszechnie dostępnych. Tłumaczenia są reprezentatywne dla zainteresowań autorki, rozpoczynającej przygodę z literaturą od opowiadań i powieści-pastiszy, by dojść do zaangażowanych społecznie i kulturowo esejów, powieści rozrachunkowych, krytycznych autofikcji i krytycznych tekstów o kulturze (Čolović 2007; Czapik-Lityńska 2009). W dorobku pisarki niezwykłe jest połączenie subtelnej wrażliwości podmiotu literackiego $\mathrm{z}$ ostrą pasją krytyczną, delikatność i humor splatają się z mrocznymi narracjami, potęgując sugestywność literackiej wypowiedzi i siłę kontestacji.

Sprzeciw wobec oficjalnej polityki i nacjonalistycznego szaleństwa doprowadził Ugrešić do emigracji. W Kulturze klamstwa (1996; wyd. pol. 1998, 2006) określiła swoją wygnańczą sytuację: „Teraz żyję za granicą i jestem tutaj tym, czym w kraju przestałam być: chorwacką pisarką. Reprezentantką kraju, w którym już nie istnieję, kraju, który opuściłam, wybrawszy wygnanie" (Ugrešić 1998: 308). Wybór emigracji i zaangażowanie

2 O tym również artykuł recenzyjny J. Kornhausera (2000: 137-145).

3 ,Tekst rozumiany hermeneutycznie pozostaje w żywym związku z osobą interpretującego. (...) Rozumienie tekstu, a tym samym obcowanie z kulturą, ma ostatecznie swój cel w tym, że służy poszerzeniu naszej samoświadomości” - pisze K. Rosner (1991: 10). Autorka tłumaczy, że podejście hermeneutyczne nie ujmuje tekstu jako zobiektywizowanego przedmiotu. Podobnie pojmuje tekst oraz kulturę Dubravka Ugrešić, której narracje służą nie tyle wiernemu opisowi, ile samorozumieniu świata i człowieka. 
w sprawy polityczne nie oznacza, że jest dysydentką. Jej aktywność nie jest zinstytucjonalizowana, działa prywatnie, pisze subiektywnie, reaguje ostro i spontanicznie. Jest pisarką bezkompromisową, kontestatorską z ducha zbuntowanej awangardy ${ }^{4}$, patrzącą na świat i sztukę inaczej, niż dopuszcza tradycja, kanon, konwencja, zwyczaj. Przekracza normy i wytyczone nimi granice, kierując się własnym doświadczeniem, własną pamięcią, własnymi wyborami.

Zanim określę specyfikę kontestacji pisarki, warto przypomnieć, że w pierwszym polskim wydaniu najbardziej oburzającej Chorwatów książki Kultura kłamstwa (eseje antypolityczne) (1998) na obwolucie umieszczono fragment wypowiedzi Adama Michnika:

Chorwacja to piękny kraj, a Dubravka jest ucieleśnieniem duchowej urody Chorwacji w literaturze. Nie znam piękniejszego kraju niż Chorwacja. I nie znam bardziej godnego patriotyzmu chorwackiego - gorzkiego jak u Miroslava Krležy - niż ten, który wyraża Dubravka.

W drugim wydaniu polskim ${ }^{5}$ zrezygnowano z komentarza Michnika. Patriotyzm Krležy był równie ambiwalentny jak patriotyzm Ugrešić. Krležy zarzucano, podobnie jak Ugrešić, projugosłowiańskość. Stanko Lasić, wnikliwy badacz twórczości Krležy uznał jego poglądy za przykład narodowej samonegacji („,nacijonalne samonegacije”, Lasić 1987: 309). Krleža jest duchowym ojcem pisarki, lecz jej postmodernistyczna perspektywa interpretacji dekonstruuje większość poglądów i mitów modernizmu, co jest tematem na inny artykuł. Ponadto, czasu krležańskiej Chorwacji ${ }^{6}$ nie sposób porównywać z czasem rozpadu Jugosławii i nową sytuacją Chorwacji.

${ }^{4}$ O specyfice i znaczeniu buntu awangardy literackiej pisałam w: Czapik-Lityńska 1996: 23-54. Literackie kontestacje awangardy chorwackiej są zakorzenione w świadomości modernistów, najpełniej w twórczości Antuna Gustava Matoša i Janka Policia Kamova. W okresie międzywojennym pasję kontestatorską i polemiczną kontynuował Miroslav Krleža. Do jego eseju-pamfletu Chorwackie kłamstwo literackie Dubravka Ugrešić nawiązuje w Kulturze kłamstwa.

${ }^{5}$ W Polsce Dubravka Ugrešić jest najczęściej tłumaczoną pisarką chorwacką, a jej teksty są na ogół właściwie rozumiane. Warto zwrócić uwagę, że Amerykański fikcjonarz nie spodobał się amerykańskim czytelnikom, którzy nie zaakceptowali ironicznego kontekstu prześmiewczego. Dla zaangażowanych w tworzenie nowej ojczyzny Chorwatów kontestacje pisarki (z czasu Kultury klamstwa) były nie do zaakceptowania.

${ }^{6}$ Cf. Czapik-Lityńska 2000. Najobszerniejszą polską publikacją o twórczości Krležy jest monografia Jana Wierzbickiego (1975). 
Moja wypowiedź jest nazbyt szkicowa, by w jakikolwiek sposób nawiązywać do skomplikowanych problemów historii Chorwacji i konfliktów wewnętrznych Jugosławii. Zagadnienie identyfikacji narodowych Krležy i Ugrešić jest możliwe do opisania w powiązaniu z kontekstami historycznymi i realiami biografii pisarskiej oraz biografii epoki.

Dubravka Ugrešić powiada o sobie, że uprawia aktywność antypolityczną. Przywołuje słowa Georga Konráda:

Antypolityka to stan zdziwienia. Człowiek odkrywa, że rzeczy są niezwykłe, groteskowe, co więcej - pozbawione sensu. Dowiaduje się, że jest ofiarą i nie chce nią być. (...) Wiarygodność antypolityki polega ni mniej, ni więcej, na tym samym, co wiarygodność pisania. To nie mowa polityka ani politologa, ani technokraty, przeciwnie: to mowa cynicznego, dyletanckiego utopisty. On nie zabiera głosu w imieniu mas czy kolektywu. Nie potrzebuje mieć za sobą partii, państwa, narodu, klasy, korporacji, świata akademickiego. Wszystko, co robi, robi na własny rachunek, osobiście, w środowisku, które sam wybrał. Z nikim nie jest zobowiązany się rozliczać, to osobiste przedsięwzięcie, samoobrona (Ugrešić 1998: 5).

Słowa Konráda dobrze ilustrują pozycję pisarki, wypowiadającej się głosem człowieka, głosem prywatnym. Dodajmy, że pisarkę interesuje świat, kultura i polityka, że pozostaje pod wpływem idei społeczeństwa obywatelskiego, otwierającej etykę antypolityki i nawiązującej do idei umowy społecznej. To trudne konteksty, osadzone w myśleniu postmodernistycznym i w słowniku pojęć płynnej ponowoczesności. Wiedzę i tożsamość pisarki wyznacza jej doświadczenie życiowe i doświadczenie literackie, zakorzenione jeszcze w modernizmie, ale osadzone i przeniknięte na wskroś ponowoczesnością. Kultura kłamstwa i zawarta w niej pasja kontestatorska spotkały się z niechęcią czytelników chorwackich i przysporzyły pisarce wielu wrogów wśród rodaków. Od esejów zawartych w Kulturze kłamstwa rozpoczęła się właściwie nagonka na pisarkę. Nie była osamotniona, bo kobiet piszących odważnie o realiach czasu wojny domowej było więcej. Najbardziej atakowane „czarownice” (cf. Dyras 2009: 43-47) były wyemancypowanymi, wykształconymi intelektualistkami (cf. Kraskowska 2003; Slapšak 2005).

Kontestacje Ugrešić determinuje niezwykle silna pasja krytyczna, której źródło tkwi w awangardowej postawie buntu, zwłaszcza w krytyczno-polemicznym podejściu Krležy do kultury, a także w sprzeciwie wywodzącym się z postmodernistycznego kanonu ironicznego, spod znaku dekonstrukcji 
i rozumu transwersalnego, szukającym porozumienia mimo odmienności. Spośród cech poetyki, odnoszonych przez krytyków do twórczości literackiej Ugrešić, takich jak polemika, intertekstualizm, autoreferencjalizm, metatekstualizm, (auto)ironia, parodia i wieloznaczność, dla postawy kontestacji ważne wydają się dwie - polemika i ironia. Polemika jest spleciona z krytyką, analizą i interpretacją tekstu, kultury, świata, ironia jest postawą dystansu ${ }^{7}$. Pisarka bardzo dobrze zna tradycję chorwackiego sporu i w gatunkach polemiczno-krytycznych znajduje doskonałe medium dla swoich kontestacji. Przypisuje się jej również poglądy feministyczne, choć sama nie deklaruje przynależności do feminizmu. Interesuje ją problematyka zmiany sytuacji kobiety w kulturze i możliwości edukacji czy emancypacji. Co znamienne, pisarkę zajmują zagadnienia istotne dla transformacji kultury, wartości i społeczeństwa. Poruszany przez nią ,syndrom kultury kłamstwa" (cf. Kornhauser 2001; Czapik-Lityńska 2002) czy problematyka tożsamości, w tym tożsamości narodowej (cf. Czapik-Lityńska 2008) należą do tego rodzaju zagadnień. Intelektualiści chorwaccy nie podjęli poważnej dyskusji, bagatelizując wartość wypowiedzi pisarki. Niewielu stanęło w jej obronie.

Polemiki i krytyki układają się w pewne modelowe typy, jak: kontestacje estetyczne, egzystencjalne, etyczne czy społeczno-kulturowe. Oczywiście nie ma wzorcowego czystego modelu, gdyż tematy nakładają się i krzyżują, podobnie jak gatunki. Najwięcej wątków estetycznych wyłożonych explicite, dotyczących sztuki, kultury i jej transformacji, zawiera zbiór esejów Czytanie wzbronione (Ugrešić 2001; wyd. pol. 2004). Poglądy krytyczne na temat rynku literatury i sztuki spotkały się z zainteresowaniem i uznaniem, jednakże w USA przysporzyły jej nowych wrogów ${ }^{8}$. Najbardziej przejmującą opowieścią o egzystencji, ludzkim losie i ludzkiej pamięci jest nostalgiczna powieść Muzeum bezwarunkowej kapitulacji (Ugrešić 1998; wyd. pol. 2002). Nazywane manifestami bezpaństwowości i nostalgicznej

7 „Ironija u službi postmodernizma hrani se skepsom vezanom uz pitanja tko smo, što smo i kamo idemo" - pisze Gordana Slabinac w artykule o awangardzie (2006: 328). Warto zwrócić uwagę, że w tomie (Benečić, Fališevac 2006) znalazły się dwa artykuły poświęcone twórczości Ugrešić.

${ }^{8}$ W wywiadzie umieszczonym przez Agnieszkę Dorotkiewicz i Annę Dziewit w książce Glośniej! Rozmowy z pisarkami Ugrešić powiedziała o Czytaniu wzbronionym: ,ta książka cieszyła się zupełnie niespodziewanym uznaniem w USA (...). To, co się zmieniło po jej publikacji, to głównie to, że mam teraz więcej wrogów, niż miałam do tej pory" (Dorotkiewicz, Dziewit 2006: 62). 
tęsknoty za przeszłością książki Ugrešić dotykają istotnych problemów chorwackiej rzeczywistości. Pisane z własnej perspektywy krytycznej, wypełnione osobistymi wyznaniami i obserwacją, oscylują między literackim dokumentem a literacką autofikcją. Z uwagi na nasycenie książek artystycznymi grami z konwencją, formą czy modą, możemy w każdej realizacji twórczej dostrzec polemikę estetyczną. Tak było z powieściami Stefcia Ćwiek w szponach życia (1981; wyd. pol. 2002) i Forsowanie powieści-rzeki (1989; wyd. pol. 1992, 2004). Pierwsza jest przykładem estetycznej polemiki z gatunkami romansowymi i ich półprawdami, druga z postmodernistyczną ideą wyczerpania literatury.

Opowiadając o rzeczywistości, która jest najtrudniejszym materiałem i najbardziej wymagającym zadaniem dla pisarza, autorka zawsze stosuje dogłębnie podmiotową perspektywę oglądu, dzięki czemu daje świadectwo własnym doświadczeniom i przeżyciom. Autoironia umożliwia dystans wobec siebie. Ironia pozwala na dystans wobec rzeczywistości. Jest też wyróżnikiem estetyki postmodernistycznej, cechą poetyki i światopoglądu oraz cechą postmodernistycznego kanonu ironicznego, który zmierzył się z metafizyczną tęsknotą za sensem esencjalistycznym, a którego zawsze w sztuce poszukiwano. Sens esencjalistyczny jest również poddany kontestacji. Do ironicznej postawy pisarki dobrze przylegają słowa Richarda Rorty’ego:

Cechą gatunkową ironistów jest brak nadziei, by cokolwiek potężniejszego od nich samych ostatecznie rozwiało wątpliwości dotyczące finalnych słowników. Oznacza to, że kryterium rozstrzygania wątpliwości, kryterium prywatnej doskonałości jest autonomia, a nie afiliacja z różną od nich mocą (Rorty 1996: 137).

Podstawą kontestacji pisarki są zatem jej autonomia, zracjonalizowane doświadczenie własne i dystans. Bez dogłębnej wiedzy o podejmowanych tematach rezultaty kontestacji byłyby znacznie skromniejsze.

Literacka refleksja krytyczna to nie tylko znakomite eseje, w których pisarka wykłada interpretacje negatywnych przeobrażeń sztuki, bezrefleksyjnie ukierunkowanej na rynek, sprzedaż i modę. Dla wielbicielki literatury, która miała być jej najważniejszą ojczyzną, rozpoznania poczynione we własnych książkach (zwłaszcza w Czytaniu wzbronionym) są szczególnie bolesne. Pisarka ceni tradycje literatury wysokiej i sama kontynuuje jej wzorce, szlifując styl, gatunek i kompozycję, rysunek i psychologię postaci, sugestywność i wiarygodność świata przedstawionego. Wcześniejsze 
teksty, jak Stefcia Ćwiek w szponach życia i Forsowanie powieści-rzeki, podejmowały istotne problemy egzystencjalne, a przede wszystkim stanowiły - jak już wspomniano - polemikę z estetycznymi modami współczesności. Powieść o Stefci jest polemiką z estetyką powieści romansowej, Forsowanie... uprzytamnia koniec dawnego typu powieści-rzeki. Obie były pisane w fazie postmodernistycznego odkrywania, że wszystko już zostało powiedziane, że dawne modele sztuki wyczerpały swoje możliwości i że literatura przeżywa kryzys. Prawdziwe kwestionowanie absurdów egzystencji stanowią powieści późniejsze.

Kontestacja literacka, skupiona w znacznej mierze na problematyce estetyki i poetyki, jest nieporównywalnie łatwiejsza do zaakceptowania (nie dotyka bezpośrednio), aniżeli kontestacja ,antypolityczna”, która zdominowała drugą fazę twórczości chorwackiej pisarki. Mimo że pisarka nie jest odosobniona w interpretacjach rzeczywistości chorwackiej, realiów polityki państwa narodowego, rozpadu Jugosławii i wojny domowej, to jej wyrażanie sprzeciwu uznano za niebezpieczne. Pojęcia państwa narodowego i tożsamości narodowej (z politycznego i kulturalnego słownika końca XX wieku) kojarzą się pisarce źle. W Polsce nie mamy uprzedzeń wobec państwa narodowego, ale jak pokazuje Philipp Ther (2012: 9), zjawisko i dramat czystek etnicznych pozostaje w ścisłym związku z państwem narodowym. Chorwaci i Serbowie nie uciekną przed upiorami niedalekiej przeszłości, a tacy pisarze jak Ugrešić nie pozwolą zapomnieć o wojennych dramatach.

Podsycanie pamięci, nagłaśnianie problematyki politycznej poza Chorwacją nie mogło być dobrze odbierane. Jednak twórczość Ugrešić stała się szybko rozpoznawalna za granicą, a jej postawa - dowartościowana pozytywnie. Teksty autorki przebiły się na europejskim rynku wydawniczym nie tylko z powodów światopoglądowych, ale także z powodów literackich. Pisarka wypracowała własną formułę literatury prawdziwej, reagującej na najbardziej palące problemy życia, wprowadziła nowego typu narracje tożsamościowe ${ }^{9}$, a kontestacje doprowadziła do perfekcji nie tylko dzięki

${ }^{9}$ Mimo że pisarka nie lubi słowa tożsamość, to właśnie jej narracje tożsamościowe są prowadzone barwnie i interesująco. Ważne miejsce wśród nich zajmują również chorwackie narracje tożsamościowe. Uwzględnia je i omawia na szerokim tle literackim i historyczno-kulturowym Magdalena Dyras (2009). 
postmodernistycznej sztuce prowokacji semantycznej oraz grom literackim, ale przede wszystkim dzięki wadze podejmowanych tematów.

Na podstawie poczynionych uwag można uznać, że Dubravka Ugrešić to mistrzyni kontestacji. To: kontestatorka estetyczna (nie godząca się na byle jaką literaturę, na literaturę wyczerpania, na słabe estetyki), kontestatorka egzystencjalna (ludzkiego bycia i ludzkiego bólu, choroby i cierpienia, absurdu i braku sensu), kontestatorka zjawisk społeczno-kulturowych i politycznych (kryzysu, nacjonalizmu, wojny, rozpadu Jugosławii - wspólnej ojczyzny, dla niektórych obywateli jedynej ojczyzny; alienacji emigracyjnej; kryzysu kultury, upadku idei wielokulturowości i idei wspólnoty ludzkiej, szerszej niż narodowa), kontestatorka tożsamości narodowej i państwa narodowego, a nawet kontestatorka pojęcia tożsamości, współcześnie wykorzystywanego do manipulacji politycznych.

Kontestacje są tym silniejsze, im bardziej powiązane są z autentycznym życiem i autentycznym podmiotem. Pisarka nie bez powodu występuje w roli świadka wydarzeń i świadka mentalności (podmiotu indywidualnego i podmiotu społecznego). Literackie świadectwa stanowią jej prywatną dokumentację życia, egzystencji, zła i nienawiści, rozpadu etyczności i elementarnych wartości decydujących o obliczu człowieka. Kategorie świadectwa i doświadczenia prowadzą pisarkę i czytelnika ku antropologicznym kontekstom interpretacji, odkrywającym na nowo myśl i doświadczenie oraz $\mathrm{ku}$ ponowoczesnej etyce hermeneutycznej ${ }^{10}$, rozpoznającej słabość bycia i poznania, także słabość konstrukcji intelektualnych.

Ugrešić ukazuje w swych książkach okrucieństwa współczesnego świata, zbrodnie wojny, przygodność i kruchość bytu, słabość człowieka, kontestuje opisywaną rzeczywistość i egzystencję. Wojenno-powojenna twórczość pisarki to znane w Polsce książki Amerykański fikcjonarz (1993, wyd. pol. 2001), Kultura klamstwa (eseje antypolityczne) (1995, wyd. pol. 1998), Muzeum bezwarunkowej kapitulacji (1999, wyd. pol. 2002), Ministerstwo Bólu (2004, wyd. pol. 2006). Podejmują problemy nacjonalistycznej nienawiści, wojny, samotności, wygnania dosłownego i metaforycznego.

${ }^{10}$ Filozof ponowoczesny traktuje sztukę ,,jako model prawdziwości, poznania, spotkania światów historycznych twórcy i odbiorcy, dzieła i interpretacji - a więc w perspektywie hermeneutycznej, traktującej prawdę jako wydarzenie" - tak o hermeneutycznej filozofii Gianniego Vattimo pisze Andrzej Zawadzki (2006: XVII). 
Podmiot literacki tych tekstów ma atrybuty współczesnego człowieka: ból, cierpienie, pamięć, pękniętą świadomość podzieloną na wczoraj i dziś, na świat wartości wspólnych i na świat poza wartościami, ujawniający absurd, chaos, entropię, rozpad. Wyobraźnia narratorki podąża głównie tropami rozpadu, melancholii, nostalgii, a więc ścieżką myślenia postmodernistycznego, myślenia o kryzysie istniejących modeli wartości, tradycyjnego dyskursu etycznego, wyznaczającego horyzont wspólny i respektowany, a zatem gwarantujący fundamentalny ład. Myślenie o rzeczywistości w rozpadzie jako dominancie czasu współczesnego przypomina „łagodny nihilizm" filozoficznej myśli Gianniego Vattimo, penetrującego doświadczenie „bezpodstawności i niemożności uzasadnienia bycia” (Vattimo 1997: 141), bycia współcześnie zdeprecjonowanego, odmitologizowanego, pozostawionego na pastwę samego siebie, nie mającego wsparcia ani w horyzoncie wspólnego fundamentu światopoglądowego, ani w horyzoncie wspólnego języka. Ponowoczesny, słaby świat jest odczuwany jako obcy, nieprzyjazny. Jego pozorna autonomia wraz z pozorną autonomią i wolnością człowieka rozpada się i kruszy w obliczu klęski człowieczeństwa, słabości sumienia, grzechu milczenia i grzechu zaniechania.

Kultura i jej wartości ukształtowały potrzebę świata bezpiecznego, uporządkowanego, etycznego. Tymczasem doświadczenia własnej egzystencji - czyli wojny, rozpadu starej ojczyzny, emigracji, wyobcowania - intensyfikują typowe dla myślenia ponowoczesnego poczucie „odrzeczywistnienia rzeczywistości”. W Amerykańskim fikcjonarzu autorka mówi o pomieszaniu fikcji i fakcji, o fantazmatycznym charakterze rzeczywistości, w której przyszło żyć: „Wydarzenia w moim kraju, który rozpadał się i znikał, przerosły najbardziej złowieszczą wyobraźnię, zatarły granice istniejących i nie istniejących światów, i ponownie znalazłam się po tamtej stronie jakiegoś innego lustra" (Ugrešić 2001: 12). W Kulturze klamstwa i w Muzeum bezwarunkowej kapitulacji opowiada o chaosie transformacji, o rozpadzie wartości:

Tak gwałtowna przemiana wartości, zachodząca w wielu dziedzinach codziennego życia - zarówno w kulturze, jak i w polityce oraz w ideologii - spowodowała zamęt w głowach wielu obywateli: złe stało się dobrym, lewica zamieniła się w prawicę. W trakcie tych przewartościowań wymazywanie historii własnego życia, zacieranie tożsamości, swoista amnezja, nieświadome lub świadome kłamstwo - stały się reakcją obronną, która umożliwia przyswojenie nowej tożsamości (Ugrešić 1998: 106). 
W ocenie i ujęciu Ugrešić przemiany rzeczywistości noszą nazbyt wiele znamion przypadkowości, ułomności, negatywności. W Muzeum bezwarunkowej kapitulacji takie postrzeganie rzeczywistości uzyskuje dodatkowy wymiar w pokawałkowanych na fragmenty narracjach o rzeczywistości, która się parabolicznie i apokaliptycznie rozpada, w słowach literackiego języka, którym pisarka notuje smutek i melancholię: „gdy patrzę ze swego okna w zimną noc, często mówię: Rozpaduje..." (Ugrešić 2002: 211).

W Ministerstwie Bólu pisarka również drąży przygodność ludzkiej egzystencji, samotność skazanych na emigrację, ich cierpienie po utracie ojczyzny, kraju: „Tak mówili, «kraj», uważnie dobierając jak najbardziej neutralny wspólny mianownik" (Ugrešić 2006: 105). Opowiadając o emigrantach, ich percepcji rzeczywistości, przepołowionej na przedwojenny czas porządku i na czas rozpadu - wojny, emigracji, chaosu, narratorka powiada:

Czas po wojnie był niby jakiś okres mityczny, w którym przestawało być ważne, czy minęło sto, dwieście czy trzysta lat. W krótkim czasie po wojnie wydarzyło się zbyt wiele. Pod tym ciężarem pękły ich mentalne zegary. Wszystko się rozpadło, przepołowiło i podzieliło (Ugrešić 2006: 105).

Dominującym akcentem tożsamościowych narracji jest zatem poczucie rozbicia, rozpadu życia i sensu. Opowieści o wykorzenieniu kwalifikują powieść Ugrešić nie tylko do powieści dokumentujących czas postjugosłowiańskiej emigracji, ale i do nowoczesnych oraz ponowoczesnych narracji „wygnańczych”, traktujących o wygnaniu dosłownym i wygnaniu jako stanie ducha wszelkich wykorzenionych, emigrantów, tułaczy, pielgrzymów, obcych i innych. Analizując sytuację współczesnego bohatera-wygnańca, Jerzy Święch sugeruje, że „Literaturę XX wieku określa swoisty «syndrom wygnania», stworzył on całą topikę" (Święch 2004: 24), w której człowiek jawi się jako wygnaniec, jako homo exul. Ministerstwo Bólu można uznać za modelową wręcz konkretyzację ponowoczesnego doświadczenia wyczerpania i rozpadu. Książkę kończy bałkańska litania nienawiści zamknięta w ludowych klątwach. Porażający komunikat negatywnych emocji prowokuje do myślenia o odpowiedzialności za słowa, ich treść, prowokuje do myślenia o wartościach i możliwości ich unicestwienia. Nosi bowiem ślady znaków kulturowych (języka, świadomości) i znaków życiowego doświadczenia. Teoretyk literatury powie dzisiaj, że kategoria doświadczenia ,jest podstawową kategorią antropologiczną, która opisuje człowieka 
zanurzonego w życiu i starającego się o tym życiu powiedzieć coś innym po to, by inni mogli go zrozumieć" (Markowski 2006). W pisarstwie zaangażowanym i kontestującym ważna jest również kategoria podmiotowości.

Kulturowa złożoność podmiotu autorskiego w obliczu rozpadu Jugosławii czyni komunikat literacki wypowiedzią dla wielu kontrowersyjną, odbieraną osobiście, w pryzmacie doświadczenia życiowego odbiorcy i jego tożsamości kulturowej (Czermińska 2003). Sytuacja współczesnego człowieka, ponowoczesnego podmiotu (regres podmiotu etycznego i autonomicznego, pozostającego spadkobiercą i dawcą sensu, relatywizm, nihilizm, zagubienie w chaosie rzeczywistości) jest rezultatem doświadczeń XX wieku (cf. Nycz, Zeidler-Janiszewska (red.) 2006). Literatura notuje ślady indywidualnych i zbiorowych doświadczeń, wydarzeń, przekonań i gustów, utrwalając je w pamięci kultury.

Wizja rozpadu rzeczywistości Dubravki Ugrešić, ruiny sensu, degradacji podmiotu etycznego nie jest, niestety, fantazmatyczna. Ukazując destrukcję modernistycznych utopii o lepszym świecie i lepszym człowieku, kontestując aktualną rzeczywistość, pisarka stawia stare pytania o wyobraźnię moralną i konsekwencje jej braku. Pyta też o odpowiedzialnych i winnych. Diagnozuje rzeczywistość z pozycji pisarki-outsiderki, bliskiej czytelnikom myślącym o współczesności w czasach wielkiej zmiany z niepokojem. Nie jest odosobniona, bo literatura chorwacka wyraża ten niepokój na wiele sposobów, odreagowując zarówno wojnę, jak i egzystencję wydziedziczoną ${ }^{11}$, sprowadzoną do instynktu przetrwania.

W wielu koncepcjach filozoficznych, między innymi w filozofii Paula Ricoeura, podmiot powraca w etyce. A etyka powraca również do myśli literackiej. Powraca w tekstach Ugrešić, wybierającej pojedynczą perspektywę reagowania na rzeczywistość, realizowaną m.in. jako podmiotowość świadka, jako podmiotowość kontestującą. Napisane, by wzruszać i by wstrząsać, są głosem pamięci i głosem przestrogi. Są pisanymi w gorączce emocji tekstami literackimi i dokumentami czasu rozpadu oraz gwałtownych transformacji.

11 Przykładów literatury o wydziedziczonych, osamotnionych, traumatycznie naznaczonych dostarcza nie tylko proza wojenna, także współczesne opowiadanie rzeczywistościowe i poezja (cf. Pieniążek-Marković, Rem i Zieliński (red.) 2005; Pieniążek-Marković 2000: 212-221). 
Krytyczne, kontestacyjne diagnozy rzeczywistości splatają się z ponowoczesnymi interpretacjami, uwzględniającymi kluczowe dla schyłku nowoczesności zagadnienia końca historii, kryzysu sztuki, śmierci człowieka, słabości podmiotu, bytu i myślenia. Pisarka interpretuje rzeczywistość, człowieka i byt w kategoriach bliskich filozofii Vattimo, którego hermeneutyka powiązana z nihilizmem pojmuje świat nie jako trwałą, mocną strukturę, lecz jako bycie słabe, narażone na niknięcie, wymagające wysiłku interpretacji, rozumienia i troski. Myślenie porażonej rozpadem wartości pisarki wpisuje się w różne wątki współczesnej myśli etycznej, zwłaszcza hermeneutycznej. Wśród nich szczególnie bliskie wydają się przemyślenia etyczne Hannah Arendt i etyka hermeneutyczna Vattimo, domagająca się wysiłku rozumienia własnego czasu i własnej kondycji, wypełnionej znakami i śladami przeszłości oraz współczesności; etyka wymagająca wiedzy i mądrości, zdolnych odczytać i zrozumieć wydarzenia bytu, transformacje kultury, znaki czasu, przesłania i przekazy. Kontestując kryzys estetyki, etyki, literatury i rzeczywistości, Ugrešić wychodzi naprzeciw wyzwaniom ponowoczesności. Jest świadkiem i uczestnikiem kultury oraz jej krytykiem.

\section{Literatura}

Biti V., 2005, Doba svjedočenja. Tvorba identiteta u suvremenoj hrvatskoj prozi, Zagreb. Čolović I., 2007, Bałkany - terror kultury. Wybór esejów, przeł. M. Petryńska, Wołowiec. Czapik-Lityńska B., 1996, „Jeszcze nie”. Utopicum jugosłowiańskiej awangardy, Katowice.

Czapik-Lityńska B., 2000, Jugosłowiańskie aporie wczesnej awangardy chorwackiej, w: Studia z historii literatury i kultury Stowian, red. B. Czapik-Lityńska, Z. Darasz, Katowice, s. 116-126.

Czapik-Lityńska B., 2002, „Syndrom kultury kłamstwa” wedlug Dubravki Ugrešić, w:

Nadzieje i zagrożenia. Slawistyka u progu nowego tysiaclecia. Studia ofiarowane Profesor Halinie Janaszek-Ivaničkovej, red. J. Zarek, Katowice, s. 313-318.

Czapik-Lityńska B., 2008, Ponowoczesne doświadczenie narodowe. Przypadek Dubravki Ugrešić, w: Bunt tradycji-tradycja buntu. Ksiegga dedykowana Profesorowi Krzysztofowi Wrocławskiemu, red. M. Bogusławska, G. Szwat-Gyłybowa, Warszawa, s. 147-162.

Czapik-Lityńska B., 2009, ,,Uwikłane w przemoc”. Žensko pismo - dyskurs emancypacyjny i krytyczny z perspektywy teorii postkolonialnej, „Porównania” nr 6, s. 165-177. 
Czermińska M., 2003, „Punkt widzenia” jako kategoria antropologiczna i narracyjna w prozie niefikcjonalnej, „Teksty Drugie” nr 2-3, s. 11-27.

Dorotkiewicz A., Dziewit A., 2006, Gtośniej! Rozmowy z pisarkami, Warszawa.

Dyras M., 2009, Re-inkarnacje narodu. Chorwackie narracje tożsamościowe w latach dziewięćdziesiątych XX wieku, Kraków.

Jelčić D., 1997, Povijest hrvatske književnosti, Zagreb.

Kornhauser J., 2000, Nowa historia literatury chorwackiej, w: Studia z historii literatury i kultury Słowian, red. B. Czapik-Lityńska, Z. Darasz, Katowice, s. 137-145.

Kornhauser J., 2001, Wielkie kłamstwo, w: idem, Świadomość regionalna i mit odrębności, Kraków, s. 214-221.

Kostić S., 2003, Post-Jugostowianka, Cyganka albo „Jakiej narodowości jest Dubravka Ugrešič”, „Poznańskie Studia Polonistyczne. Seria Literacka” t. 10, s. 103-110.

Kraskowska E., 2003, Dubravki Ugrešić filologia antytotalitarna, „Poznańskie Studia Polonistyczne. Seria Literacka" t. 10, s. 111-121.

Kraskowska E., 2007, Płeć Slowiańszczyzny, w: Nasza środkowoeuropejska ars combinatoria, red. K. Pieniążek-Marković, G. Rem, B. Zieliński, Poznań, s. 349-360.

Lasić S., 1987, Mladi Krleža i njegovi kritičari (1914-1921), Zagreb.

Markowski M.P., 2006, Antropologia, humanizm, interpretacja, w: Kulturowa teoria literatury. Glówne pojęcia i problemy, red. M.P. Markowski, R. Nycz, Kraków, s. $137-152$.

Nycz R., Zeidler-Janiszewska A. (red.), 2006, Nowoczesność jako doświadczenie, Kraków.

Pieniążek-Marković K., 2000, Ekspresje (nie)podmiotowości i (nie)tożsamości w najnowszej poezji chorwackiej, w: Literatury stowiańskie po roku 1989. Nowe zjawiska, tendencje, perspektywy. Podmiotowość, t. 3, red. B. Czapik-Lityńska, Warszawa, s. 212-222.

Pieniążek-Marković K., Rem G., Zieliński B. (red.), 2005, Widzieć Chorwację. Panorama literatury i kultury chorwackiej 1990-2005, Poznań.

Rorty R., 1996, Przygodność, ironia i solidarność, przeł. W.J. Popowski, Warszawa.

Rosner K., 1991, Przedmowa, w: eadem, Hermeneutyka jako krytyka kultury. Heidegger, Gadamer, Ricoeur, Warszawa, s. 10.

Slabinac G., 2006, Hiperbolički diskurs avangarde, w: Čovjek, prostor, vrijeme. Književnoantropološke studije iz hrvatske književnosti, red. Ž. Benčić, D. Fališevac, Zagreb, s. 325-341.

SlapšakS.,2005,Feminizmipisarstwokobietnapoluminowym.Paradygmatjugosłowiański $i$ postjugosłowiański $w$ perspektywie synchronicznej $i$ diachronicznej, w: Literatury stowiańskie po 1989 roku. Feminizm, t. 2, red. E. Kraskowska, Warszawa, s. $137-168$. 
Święch J., 2004, „Homo exul”, parę uwag o topice nowoczesności, „Teksty Drugie” nr $1-2$, s. 22-42.

Ther Ph., 2012, Ciemna strona państw narodowych. Czystki etniczne w nowoczesnej Europie, przeł. T. Fabiś, Poznań.

Ugrešić D., 1995, Forsowanie powieści-rzeki, przeł. D. Ćirlić-Straszyńska, Warszawa.

Ugrešić D., 1998, Kultura klamstwa (eseje antypolityczne), przeł. D.J. Ćirlić, Wrocław.

Ugrešić D., 2001, Amerykański fikcjonarz, przeł. D.J. Ćirlić-Straszyńska, Wołowiec.

Ugrešić D., 2002, Muzeum bezwarunkowej kapitulacji, przeł. D.J. Ćirlić, Izabelin.

Ugrešić D., 2004, Czytanie wzbronione, przeł. D.J. Ćirlić, Izabelin.

Ugrešić D., 2006, Ministerstwo Bólu, przeł. D.J. Ćirlić, Izabelin.

Ugrešić D., 2008, Nikogo nie ma w domu, przeł. D.J. Ćirlić, Kraków.

Vattimo G., 1997, Ponowoczesność i kres historii, w: Postmodernizm. Antologia przekładów, red. R. Nycz, przeł. B. Stelmaszczyk, Kraków, s. 137-168.

Wierzbicki J., 1975, Miroslav Krleža, Warszawa.

Zawadzki A., 2006, Koniec nowoczesności: nihilizm, hermeneutyka, sztuka, w: G. Vattimo, Koniec nowoczesności, przeł. M. Surma-Gawłowska, Kraków, s. V-XXI. 


\title{
Kontestacja à rebours. O pisarstwie i nie-pisarstwie Karla Michala
}

\begin{abstract}
Czernikow Olga, Kontestacja à rebours. O pisarstwie i nie-pisarstwie Karla Michala (Contestation à rebours. On Writing and Non-Writing of Karel Michal). „Poznańskie Studia Slawistyczne" 6. Poznań 2014. Publishing House Science and Innovate, pp. 63-74. ISBN 978-83-63795-51-1. ISSN 2084-3011.

The problem of transfer from the official to the unofficial culture is one of the most significant phenomena in the post-war Czech literature history. Resistance against the limitations on creative autonomy set by the government led to the emergence of particular contestation attitudes and to the creation of counterculture, understood as a dissident and exile culture, as well as the underground. In this landscape, Karel Michal's position is peculiar and difficult to classify; his contestation is total, as it is pointed at not only the subordination of literature to norms set by the regime, but also at the expectations put on it by the dissident community. In texts which appeared during his exile, he presents an uncompromising approach to the issue of the engagement of literature and roles assumed by a writer arbitrarily. A consequence of his radical position is the growing imperative to not write, which leads to his complete withdrawal from literary life.
\end{abstract}

Keywords: Karel Michal; exile literature; censorship; contestation; negation; identity

Josef Kroutvor w swojej znanej książce Potiže s dějinami pisze o wychodźstwie jako modelowym przykładzie tytułowych kłopotów z historią, polegających w tym wypadku na radykalnej zmianie w postrzeganiu przeszłości i teraźniejszości. Emigracja sytuuje jednostkę poza procesem dziejowym w roli obserwatora, który świadomie percypuje tenże proces (Kroutvor 1990: 125). W konsekwencji emigrant, będąc niejako na orbicie wydarzeń (a nie, jak do tej pory, w ich centrum), postrzega zarówno historię w materialnej procesualności, jak i pozycję, jaką zajmuje. Innymi słowy, dopiero będąc „na zewnątrz” historii, może w pełni zdać sobie sprawę z jej istnienia. Opozycję wewnątrz - na zewnątrz Kroutvor rozpatruje w kategoriach czasowych („było - jest” czy też „wtedy - teraz”), trzeba jednak zauważyć także analogiczne przeciwstawienie w obrębie relacji przestrzennych. 
Emigracja oznacza przecież opuszczenie jednego terytorium i osiedlenie się na drugim. Tym samym binarne przeciwieństwa współistnieją w superpozycji: „teraz i wtedy” oraz „tutaj i tam”. Nakładanie się dwóch negatywnych (bo będących poza zasięgiem podmiotu, a zatem nieobecnych w jego percepcji) planów - czasu i przestrzeni - determinuje los pisarza emigranta, którego drogę twórczą w nowej rzeczywistości wytyczają współrzędne podwójnego wyobcowania. W tej perspektywie continuum tożsamości zostaje zakwestionowane, a sama tożsamość jawi się jako coś nieoczywistego, jako nietrwała struktura, którą trzeba wciąż na nowo rekonstruować.

Dychotomia czasoprzestrzenna przekłada się też na metodologię badań, pozwala bowiem definiować i postrzegać literaturę emigracyjną nie tylko w kontekście terytorialnym (jako literaturę powstałą za granicą), ale także historycznym (jako rezultat określonych procesów). W ten sposób zjawiska w obrębie literatury emigracyjnej (czy też - w szerszym kontekście - literatury niezależnej) podlegają interpretacji zarówno w wymiarze diachronicznym, jak i synchronicznym. W pierwszym przypadku mowa o ustaleniu mechanizmów przejścia ze sfery literatury oficjalnej do nieoficjalnej, w drugim - o wyodrębnieniu modelowych postaw, reprezentowanych przez twórców, którzy takiego przejścia dokonali. Schemat transferu jest znany: kiedy nadrzędny wobec twórcy system (polityczny, społeczny czy religijny) utrudnia, ogranicza lub wręcz uniemożliwia indywidualny i nieuwarunkowany doktrynalnie przekaz, dochodzi do konfliktu na płaszczyźnie twórca - establishment, którego rezultatem jest albo kompromis, albo świadoma rezygnacja z uczestnictwa w kulturze oficjalnej. W zależności od drogi, którą pójdzie kontestator, wystąpienie (dobrowolne lub wymuszone) z głównego nurtu może oznaczać przejście do artystycznego podziemia, emigrację wewnętrzną lub do innego kraju (systemu). Według tych wyborów kształtują się odpowiednio postawy dysydenta, twórcy undergroundowego albo emigranta. W każdym z przypadków, zakładanym rezultatem schizmy, jaką staje się transfer z kultury oficjalnej do nieoficjalnej, jest odzyskanie niezawisłości twórczej wypowiedzi, możliwość publikowania (co prawda często jedynie dla niewielkiego grona wtajemniczonych, jak w przypadku wydawnictw samizdatowych) lub zapewnienia sobie innych form kontaktu z odbiorcą. Opisany mechanizm - z większymi lub mniejszymi odchyleniami - można dostrzec w losach setek pisarzy niezależnych, których biografie i bibliografie tworzą alternatywny leksykon literatury danego obszaru. Zauważyć go 
można niewątpliwie także u Karla Michala, którego twórczość jest tematem niniejszego artykułu. W przypadku autora Straszydet przedstawiony wyżej algorytm działa jednak wbrew przewidywaniom.

Kiedy Michal we wrześniu 1968 roku decyduje się opuścić Czechosłowację, jest już cenionym i chętnie czytanym autorem. Krótko po spektakularnym sukcesie debiutanckiego opowiadania Plívník dlaždiče Housky (1959) wydaje nowelę kryminalną Krok stranou (1961) i zbiór opowiadań Bubáci pro všední den (1961). W drugiej połowie lat 60. XX wieku wychodzi eksperymentalne opowiadanie Gypsová dáma oraz powieść historyczna Čest a sláva, której filmowa adaptacja Hynka Bočana przynosi pisarzowi międzynarodowy rozgłos (film otrzymuje nagrodę między innymi na festiwalu w Wenecji w 1969 roku). To jednak Straszydła na co dzień są książką, którą Michal trwale zapisał się w świadomości czytelniczej, zyskując zarazem jednomyślny aplauz krytyki. Interesujący jest fakt, że ów cykl opowiadań, bezlitośnie obnażających absurdy życia w państwie socjalistycznym, z równym powodzeniem figuruje na liście lektur ówczesnych kontestatorów, jak i w oficjalnym kanonie powojennej literatury czeskiej.

Jako autor Michal funkcjonuje więc na granicy dwóch obszarów - kultury oficjalnej i nieoficjalnej - konsekwentnie unikając jednak arbitralnego przyporządkowania do któregokolwiek z nich. Nie jest ulubieńcem władz, ale nikt go nie szykanuje. Po wielu latach pracy (przeważnie fizycznej) na najniższych stanowiskach, doczekuje się w końcu posady lektora w wydawnictwie Naše vojsko, co zapewnia mu stabilizację materialną i zawodową. Decyzja o emigracji nie zapada jako następstwo traumatycznych doświadczeń, dotykających pisarza osobiście, nie wynika z boleśnie odczuwanego ograniczenia swobód obywatelskich czy wolności słowa. Michal nie jest zmuszony do opuszczenia kraju - ani bezpośrednio przez nakaz władz, ani pośrednio przez brak możliwości twórczego realizowania się. To decyzja podyktowana silnym wewnętrznym imperatywem, radykalną niezgodą na uczestnictwo - choćby w charakterze świadka - w procesie, którego siłą napędową są absurd i relatywizacja wartości, z takim zacięciem piętnowane w jego utworach. Wkroczenie wojsk Układu Warszawskiego stało się bodźcem do podjęcia decyzji, która dojrzewała od dłuższego czasu. Należy podkreślić szczególny charakter postanowienia Karla Michala: ówczesna sytuacja życiowa pisarza nie wskazywała na to, że opuszczenie kraju mogłoby być konieczne lub w jakikolwiek sposób korzystne. Osobliwy, silnie 
uwewnętrzniony akt kontestacji Michala nadaje szczególny rys jego losom na wychodźstwie. Pobyt pisarza w Szwajcarii przebiega pod znakiem wycofania, rezygnacji i uporczywego podawania w wątpliwość własnego statusu jako twórcy. Program metodycznej negacji - o czym będzie jeszcze mowa - stanie się dla Michala fundamentem kreowania autorskiego ja. Pisarz konsekwentnie odmawia uczestnictwa w życiu publicznym, unika zaangażowania w sprawy emigrantów, ale też odrzuca przywileje przysługujące mu z racji statusu uchodźcy politycznego. Mechanizm przejścia z kultury oficjalnej do nieoficjalnej działa więc w jego przypadku w zgoła nieoczekiwany, przewrotny sposób: przyjazd do demokratycznego państwa nie tylko nie otwiera przed autorem Straszydet... nowych perspektyw twórczej realizacji, lecz także skłania go do porzucenia również dotychczasowych. Emigracji terytorialnej towarzyszy więc emigracja wewnętrzna. W ten sposób Michal staje się dysydentem w pierwotnym i uniwersalnym znaczeniu tego słowa: jest tym, kto „siedzi po przeciwnej stronie” (dissidere), protestuje przeciw arbitralnie przyjętym formom podporządkowania. Buntuje się niejako podwójnie: poprzez wychodźstwo wyraża sprzeciw wobec systemu totalitarnego, poprzez emigrację wewnętrzną - odrzuca role, jakie mu narzuca emigracyjna (i nie tylko) społeczność. W tym sensie kontestuje więc samą kontestację.

Takie stanowisko zajmuje też w pierwszym wydanym po wyjeździe utworze, krótkim eseju - czy raczej przemowie - pod tytułem Přemilí souse$d e^{1}$ (Michal 2001a). Jest to bez wątpienia jeden z najbardziej zagadkowych i trudnych w odbiorze tekstów autora Kroku stranou, zarówno ze względu na skomplikowany plan formalny, jak i zawarte w nim treści. Kolejne sensy odsłaniają się stopniowo i nie wprost, w ironicznej perspektywie nawarstwiających się zaprzeczeń. Pretekstem do przedstawienia owej osobliwej mowy jest próba podsumowania koegzystencji przybysza-cudzoziemca i jego sąsiadów. Refleksja ta daje asumpt do rozmaitych uwag (wyrażanych zazwyczaj aluzyjnie) pod adresem obu stron ( $\mathrm{tj}$. przybysza i sąsiadów, a w szerszym kontekście - Czechów i Szwajcarów), rychło przeradzających się w bezlitosną drwinę. Utwór ukazał się w 1972 roku w antologii Das

${ }^{1}$ Ze względu na temat i objętość niniejszego artykułu omówienie tego utworu musiało zostać ograniczone do przedstawienia jednej tylko linii problemowej. Szczegółowej analizie Přemilých sousedi̊ poświęciłam odrębne studium (Czernikow 2010: 381-390). 
kalte Paradies. Emigration - Intergration - Konfrontation, potem zaś został przedrukowany w emigracyjnym czasopiśmie „Zpravodaj”. Esej wywołał histeryczną reakcję czeskich emigrantów, których oburzała nie tyle czytelna w tekście kpina z ich narodu, ile cierpkie aluzje pod adresem Szwajcarów. Do redakcji napływały listy, w których czytelnicy w mniej lub bardziej agresywny sposób potępiali Michala za to, że „kala nie tylko swoje gniazdo, ale i to szwajcarskie” (Fischerová 2008: 159) oraz że z jego winy „nasze dzieci nie będą miały wstępu do szkół wyższych, a naszym przedsiębiorcom zakaże się prowadzenia działalności” (Fischerová 2008: 159).

Absurdalny charakter zarzutów dowodzi czegoś więcej niż tylko powierzchownej lektury i niemożności czy niechęci dostrzeżenia głębokich, acz nieoczywistych sensów, kryjących się w wielowarstwowej strukturze utworu. Wskazuje przede wszystkim na problem, z którym czeska literatura emigracyjna - być może też czeska literatura w ogólności ${ }^{2}$ - borykała się przez wiele lat, a który wówczas stał się szczególnie dotkliwy. Chodzi o przyjęte a priori przeświadczenie o funkcjonalnym charakterze literatury, o jej politycznej czy społecznej roli. Takie podejście narasta w okresie zagrożenia dla continuum dziedzictwa kulturowego. Na emigracji groźba zerwania ciągłości jawi się w ekstremalnej formie jako gwałtownie postępujący i nieuchronny proces, przeciwko któremu należy jak najszybciej przedsięwziąć środki zaradcze. Nawiązywanie do przeszłości (pojmowanej nie tylko w kategorii czasowej, ale i przestrzennej; nie tylko ,wtedy”, ale również „tam”) i zintensyfikowana refleksja nad wydarzeniami poprzedzającymi emigrację mają stać się antidotum na dokonujący się - lub niemal już dokonany - rozłam. Od twórcy oczekuje się ,scalania” pamięci narodowej, gotowości do nieustannego zaświadczania o tym, co było. Świadectwo pisarza zyskuje podwójną wartość - po pierwsze dla samej diaspory, stając się czynnikiem reintegrującym tożsamość kulturową, po drugie dla zagranicznej opinii publicznej jako wypełnienie faktograficznej luki. Ten stan

2 Wnikliwą analizę konfliktu pomiędzy arbitralnie przyjętym programem czeskiej literatury narodowej a indywidualną potrzebą ekspresji przedstawił Josef Jedlička w swoim eseju Okraj a střed. „V Čechách byl obsahem uměleckého vývoje vždycky spor mezi objektivní potřebou vytvořit členitou, obsáhlou a dosti reprezentativní národní kulturu a potřebami jednotlivého umělce, který chtěl své dílo naplnit pravým, životným a personálně zaručeným obsahem. Čím organizovanější a programovější byla ona objektivní potřeba, tím více byl skutečný tvůrce zatlačován na okraj” (Jedlička 2009: 78). 
rzeczy zaczyna być problemem, kiedy ulega pewnej automatyzacji, a samo zabranie głosu w społecznej lub politycznej dyskusji zyskuje status wydarzenia literackiego. Wobec absencji niezależnej krytyki na wychodźstwie coraz wyraźniej uwidacznia się ryzyko utylitaryzacji literatury. Konsekwencją takiego podejścia jest sytuacja, w której pisarz musi wypowiadać się jako komentator życia społecznego, zajmować stanowisko w sprawach niejednokrotnie bardzo odległych od literatury. Tekst siłą rzeczy staje się podrzędny wobec kontekstu. Michal sprzeciwiał się takiej wizji twórczości, podobnie jak panującemu w środowisku emigranckim przekonaniu o konieczności zajęcia przez pisarza określonego stanowiska: krytycznego wobec systemu, który opuścił, i pochlebnego wobec porządku, który go przyjął. Kontestując postulat zaangażowania, wypowiadania się w imieniu społeczności i jej spraw, Michal staje więc w opozycji do przedstawicieli elit emigranckich, jest dysydentem wśród dysydentów.

Rozgłos i uznanie, jakie przyniosła Michalowi publikacja kontrowersyjnego eseju, zaowocowały propozycją współpracy ze strony szwajcarskiej telewizji, która zamówiła sztukę opartą na motywach Wojny peloponeskiej Tukidydesa. Historia małej wyspy Melos, broniącej swojej suwerenności w obliczu zagrożenia ze strony Sparty i Aten, miała w założeniu stać się pochwałą szwajcarskiej neutralności i demokracji. I w tym wypadku ujawnił się Michalowski duch przekory - tekst, zatytułowany Wir, die Bürger von Melos (Michal 2001b), okazał się bowiem ponurym rewersem tej krzepiącej wizji: w podaniu autora Straszydeł Melijczycy są słabym i biernym narodem, niezdolnym do zjednoczenia się i podjęcia jakichkolwiek kroków nawet w chwili niebezpieczeństwa. Przemoc, której dopuszczają się Ateńczycy, jest w pewnym sensie naturalnym następstwem pasywności ofiar. Inaczej niż u Tukidydesa, w sztuce Michala najeźdźcy nie podejmują żadnych negocjacji, ale od razu przystępują do krwawej ofensywy. Świadomi swojej siły, stawiają ofiarom ultimatum: Melijczycy mogą uniknąć śmierci, jeśli poddadzą się kastracji.

Szwajcarscy producenci uznali, że tekst w takiej formie jest nie do przyjęcia: poprosili autora o zmianę zakończenia i złagodzenie drastycznego wydźwięku sztuki. Pisarz uciął dyskusję lakonicznym stwierdzeniem, że na takie ustępstwa nie szedł nawet wobec żądań komunistów, nie widzi więc powodu, dlaczego miałby je robić teraz (Štulcová 2005: 185-86). Wobec bezkompromisowego i nieugiętego stanowiska Michala, zuryska stacja 
zrezygnowała z produkcji, a tekst sztuki ukazał się dopiero w 1991 roku w czeskim przekładzie Violi Fischerovej. Pozostaje tyle zabawnym, ile osobliwym paradoksem - jednym z wielu w biografii autora Gipsowej damy że po latach doświadczeń w ustroju programowo ograniczającym wolność słowa, to właśnie w demokratycznej Szwajcarii twórczość Michala spotkała się z solidnym oporem ze strony cenzury.

Problemy, które towarzyszyły publikacji Najdroższych sasiadów i wystawieniu sztuki My, obywatele Melos, stały się tematem artykułu Možnost volit (Michal 2001c), który Michal wygłosił w 1977 roku na sympozjum „Letteratura e dissenso" w ramach weneckiego Biennale ${ }^{3}$. Tym, co uderza już od pierwszych linijek tekstu, jest chłodny, zobiektywizowany ton wypowiedzi. Michal pisze o sytuacji pisarza emigranta $\mathrm{z}$ dystansem, sugerującym, że problem dotyczy go w niewielkim stopniu - jakby chodziło o wydarzenia, które rozegrały się jakiś czas temu i nie mają już większego znaczenia. Pozorne niezaangażowanie podmiotu autorskiego manifestuje się także w użyciu pierwszej osoby liczby mnogiej, wskazującym na obecność jakiejś zbiorowości, w której ,ja” zatraca swoją odrębność. Napięcie pomiędzy ,ja” a „nie-ja” przenika zresztą całą twórczość emigracyjną autora Straszydel, czyniąc ją trudną w interpretacji, niemal nieczytelną. Tak jest i w tym przypadku - ,ja" mówiącego podmiotu depersonalizuje się już to w bezosobowym my, już to w modelowej i hipotetycznej postaci anonimowego pisarza, czy w końcu w groteskowym fantazmacie przerośniętego szczeniaka, będącego alegorią twórcy rozpieszczanego i jednocześnie niewolonego przez władzę lub opinię publiczną. Wydaje się, że nawet w artykule konferencyjnym Michal ujawnił potrzebę zamanifestowania umowności, a więc i hermetycznie pojmowanej „literackości” swojego - i każdego - tekstu. Problem uwikłania literatury w inne dziedziny życia społecznego (tak obcy reprezentowanej przez niego postawie), staje się środkiem ciężkości w analizie sytuacji pisarza tworzącego w warunkach reżimu:

Většina z nás začala vykonávat povolání spisovatele v systému, který svoje funkce spíše supluje, nežli vykonává, jak už vykonávat není s to. Literatura supluje publicistiku, lidovýchovu, politickou reklamu, často politiku samu. Spisovatel, chce-li vůbec publikovat,

3 Wystąpienie Michala zostało pierwotnie opublikowane w czasopiśmie „Listy” (nr 8, 1978), w niniejszym artykule cytuję z przedruku zamieszczonego w wydaniu z 2001 roku (Michal 2001c). 
musí suplovat za neschopnou, zato však všemocnou vrchnost, jež ho za to chválí či kárá, často stř́́davě, ještě častěji současně. Může existovat jen jako náchlebník, sociální př́ípad i proti své vůli, dítě par excellence: jednou jako občan, jednou jako autor (Michal 2001c: 663).

Kontrapunktem dla tej diagnozy jest cierpka wizja pisarza w pluralistycznym systemie, w którym literatura jest tylko jednym (bynajmniej nie niezbędnym) z wielu elementów działalności, funkcjonującej na zasadach wyznaczanych i regulowanych przez wolny rynek.

Ta druhá [společnost] na rozdíl od první svoje funkce zhusta reálně vykonává, a pokud supluje, pak zrrídka takzvaným krásným písemnictvím. Chcete-li, nemá na něm zájem, či rozhodně ne víc než si literatura dle mého názoru objektivně zaslouží. V každých novinách je napřed politika, potom hospodářství, pak zlomené nohy a sportovní stránka. Kulturní rubrika přichází nakonec, pak už jen vtip týdne. A jelikož vlastně k ničemu moc není, může si autor žít pod skříni a chodit na lovy, když nechce panečkovi na klín. Vykonává zhusta svoje spisování co zájmovou činnost, drobný odborný řemeslník, který pracuje pro úzký kruh zájemců (Michal 2001c: 663-664).

Obraz pisarza wyrobnika, wykonującego - jak każdy rzemieślnik w swojej specjalności - przyjęte zlecenie, za które dostaje pieniądze, staje się leitmotivem późniejszych wypowiedzi autora Straszydet na temat jego twórczości. Umniejszanie własnego znaczenia, porównywanie swojego pisarstwa do kiepsko opłacanego rzemiosła, tworzy linię wyznaczającą kierunek autokreacji Michala, aż do jego samobójczej śmierci w 1984 roku. Wydaje się, że podjęcie tego rodzaju gry było przewrotnym aktem sprzeciwu wobec nakładanych na twórcę zobowiązań. Autodeprecjacja, odmowa uczestnictwa w życiu literackim, stały się wentylem bezpieczeństwa: nie będąc pisarzem, nie podlega się ubezwłasnowolnieniu ze strony władz lub publiczności. Dla Michala-kontestatora był to swego rodzaju azyl, w którym mógł się schronić razem ze swoją wizją literatury wolnej od zaangażowania innego niż literackie. Odrzucenie roli pisarza oznaczało, jak można wywnioskować z powyższego cytatu, zdeprecjonowanie własnego znaczenia, ale jednocześnie umożliwiało emancypację woli, wydostanie się ze stanu „dziecięctwa”, to jest zupełnego podporządkowania „dorosłej” instytucjonalizacji. Koncepcja Michala przyjmuje więc formę tyleż radykalnej, co paradoksalnej tezy: wolność można uzyskać jedynie poprzez odrzucenie wolności - przy czym przez tę pierwszą należy rozumieć niezawisłość 
dzieła i procesu twórczego, przez tę drugą zaś nominalną (a zarazem pozorną) niezależność gwarantowaną przez sam status dysydenta czy emigranta. Uzyskanie tej pierwszej jest dla twórcy - według autora Straszydet - punktem odniesienia i celem, dla którego należy poświęcić tę drugą. Michal pisze o tym w zakończeniu omawianego eseju:

Kdo si nechce uhnít, ten musí začinat vždy znovu, dovnitř a navenek. A kdo se nechce dát krmit a vyplácet na zadek, nebot' prostě nechce, nežádá soucitu, leč ani obdivu jen za to, že nechce, at' už je snad autor nebo ne. Stal se z něho, alespoň v tomhletom dohledu, totiž dospělý pes (Michal 2001c: 664-665).

Program metodycznego negowania swojej roli jako twórcy z czasem urasta do rangi osobliwego rytuału, chorobliwego natręctwa, które szybko staje się drugim ,ja” autora. Negacja zaczyna mieć wymiar totalny: Michal nie publikuje, nie uczestniczy w życiu literackim i konsekwentnie wypiera się jakichkolwiek twórczych inklinacji (cf. Hvížd’ala 1981: 133). Staje się więc - niczym Oskar Měštáček z powieści Oty Filipa - „niepiszącym pisarzem" (Filip 2008), autorem, dla którego literatura jest rodzajem nieszkodliwego hobby. Jak już wspomniano, jest to forma autokreacji, rodzaj gestu czy też pozy, która z jednej strony wyraża właściwą naturze Michala przekorę, z drugiej zaś oznacza szansę na zachowanie niezależności, zwolnienie z obowiązku bycia dysydentem ,na pełny etat”. Owa świadomie przyjęta rola w sferze życia publicznego w zaskakujący sposób przekłada się także na sferę indywidualną, sferę ,ja" rozumianego jako podmiot twórczy. O ile jednak wobec innych Michal wypiera się swojego pisarstwa, o tyle wobec samego siebie odmawia go sobie.

W tym okresie bowiem (a mowa tu o ostatnich kilku latach przed samobójczą śmiercią autora) Karel Michal pracuje nad dwiema książkami, od ukończenia których w pewnym sensie sam się powstrzymuje. Żadna z nich się zresztą nie zachowała (oba rękopisy zaginęły), a informacje o ich treści i charakterze znane są tylko z relacji Violi Fischerovej i najbliższych przyjaciół pisarza. Pierwszą z nich, zatytułowaną Ach, synku, synku, zaczął pisać latem 1980 roku. Po kilku dniach wytężonej pracy, której efektem był ponaddwustustronicowy szkic, Michal przerwał nagle pisanie i więcej już do niego nie wrócił (na podstawie korespondencji autorki tekstu z Violą Fischerovą, 08.06.2009). Druga pozycja była zbiorem rozmaitych absurdalnych historii, których autor doświadczył w czasie służby wojskowej i pracy na 
najniższych szczeblach socjalistycznego państwa. Choć koncepcja powieści zrodziła się zaraz po przyjeździe do Szwajcarii, Michal zaczął myśleć o jej napisaniu dopiero na początku lat 80 . Powrót do tego pomysłu po kilkunastu latach dowodzi, że tekst powstawał z silnej wewnętrznej potrzeby, której nie osłabił nawet dystans czasowy. Działo się to jednak w okresie, w którym ,program negacji” zdominował już na dobre działalność autora; procesowi twórczemu siłą rzeczy musiały więc towarzyszyć sprzeczne odczucia. Wydaje się, że Michal chciał napisać książkę, której pisania jednocześnie sobie odmawiał. Pisarstwo (czy raczej nie-pisarstwo) Karla Michala znalazło się w położeniu, którego paradoksalny charakter najcelniej oddawałaby prawdopodobnie formuła Melville'owskiego Bartleby'ego: blokujące jakiekolwiek działanie „wolałbym nie”. Rezultatem owej autokontestacji był tekst, który można określić mianem antyautobiografii. Historie, które przytrafiały się pisarzowi, zostały rozdzielone pomiędzy fikcyjnych bohaterów, z których żaden nie był tożsamy z ,ja” podmiotu autorskiego. Ta technika przywodzi na myśl metodę Roberta Walsera - twórcy, o którym Elfriede Jelinek pisała jako o ,jednej z tych osób, które mówiąc «ja», nigdy nie mają na myśli siebie" (Jelinek 1998: 48).

Przywołanie nazwiska szwajcarskiego pisarza nie jest w tym kontekście przypadkowe. Wydaje się bowiem, że w losach tych dwóch autorów, tak odległych epoką, estetyką i charakterem, można dostrzec zaskakujące podobieństwa. Walser, który mówił o sobie jako o ,powieściopisarzu-rzemieślniku”, ,pisarskim tokarzu” (Żychliński et al. 2013: 125), będąc u szczytu sławy, nagle przestał tworzyć, po czym dobrowolnie przeniósł się do zakładu dla nerwowo chorych. Konsekwentnie wymawiał się od pisania, a kiedy opiekujący się nim Carl Seelig usiłował namówić go do powrotu do literatury, odpowiadał, że ,jest w zakładzie od tego, żeby być wariatem, a nie od tego, żeby pisać książki” (Coetzee 2000). Jako „niepiszący pisarz” autor Jakoba von Guntena zaczął tworzyć tak zwane mikrogramy - miniaturowe teksty, notowane ołówkiem na serwetkach, rachunkach czy skrawkach gazet. Utwory z ,obszaru ołówka”, jak nazywał je sam Walser (Żychliński et al. 2013: 129) to eseje, opowiadania i listy, zapisywane czcionką, której wysokość nie przekraczała dwóch milimetrów. W ten sposób powstało ponad pięćset kart tekstów, które aż do lat 70. XX wieku uchodziły za niemożliwe do odczytania (uważano zresztą, że są nie tylko nieczytelne, ale również zaszyfrowane). Powieść Zbój, odcyfrowana w 1972 roku, oraz 
krótkie utwory prozatorskie odczytane w latach 1981-2000 są materialną dokumentacją walki, którą szwajcarski outsider musiał wówczas stoczyć sam ze sobą - walki pomiędzy odmawianiem sobie pisania a odczuwaną wewnętrznie koniecznością komunikacji literackiej. Tworzenie nieczytelnych, ,niewidzialnych” tekstów umożliwiło wyjście z tej aporii i jednocześnie usytuowało Walsera na rubieżach historii literatury, poza wszelkimi prądami i tendencjami, w pewnym sensie także poza samą literaturą.

Paralele z losem Michala rysują się całkiem wyraźnie. Absolutny (bo nieznający wyjątku) charakter jego postawy jako kontestatora sprawił, że przejście z obszaru kultury oficjalnej do nieoficjalnej miało zupełnie inny rezultat niż w przypadku większości pisarzy emigrantów. Uzyskanie statusu, który dla dysydenta oznacza cel i kres transferu pomiędzy dwoma obszarami kulturowymi, dla autora Straszydet okazał się tylko stadium pośrednim w procesie realizacji właściwej mu koncepcji niezależności. W jego przypadku bowiem trakt ten wiódł nie tylko poza literaturę podlegającą systemow i, lecz także - podobnie jak u Walsera - poza literaturę p oj m ow a ną jako system. Ta peryferyjna pozycja czyni z Michala outsidera, którego dzieło nie pasuje do żadnego kanonu, wymyka się próbom systematycznego ujęcia, uszeregowania w ramach danego kontekstu historyczno- czy teoretycznoliterackiego. Określenie się poprzez nie-pisanie prowadzi bowiem do punktu, w którym wszelka kategoryzacja zostaje unieważniona. Ma to dwojakie konsekwencje: $\mathrm{z}$ jednej strony pisarz emigrant poniekąd sam skazuje się na banicję (podwójną), świadomie wykluczając się z literatury poprzez utrudnienie lub uniemożliwienie recepcji swojego dzieła, z drugiej zaś zyskuje szansę na uwolnienie własnej twórczości od balastu utylitaryzmu, a co za tym idzie, osiągnięcie rzeczywistej niezależności. Jest w tym rozstrzygnięciu oczywiście coś paradoksalnego: żeby ocalić swoje pisarstwo, trzeba w pewnym sensie z niego zrezygnować. Przypadek Karla Michala pokazuje, że podjęcie tak radykalnej decyzji jest możliwe, co więcej - kiedy stawką jest autonomia aktu twórczego, staje się koniecznością, nawet za cenę ryzyka, jakie ze sobą niesie. 


\section{Literatura}

CoetzeeJ.M.,2000, The genius of Robert Walser, ,The New York Review ofBooks”, $<$ http:// www.nybooks.com/articles/archives/2000/nov/02/the-genius-of-robertwalser/?pagination $=$ false $>, 28.06 .2013$.

Czaplińska J., 2006, Tożsamość banity. Problematyka autoidentyfikacji w młodej czeskiej prozie emigracyjnej po 1968 roku, Szczecin.

Czernikow O., 2010, Identita na rozhraní. Já a ne-já v eseji Přemilí sousedé Karla Michala, w: Česká literatura rozhrani a okraje. IV. Kongres světové literárněvědné bohemistiky Jiná česká literatura (?), red. L. Jungmannová, Praha, s. 381-390.

Filip O., 2008, Sasiedzi i ci inni, przeł. J. Stachowski, Wrocław.

Fischerová V., 2008, O straszydłach Karla Michala, przeł. D. Dobrew, w: K. Michal, Straszydla na co dzień, przeł. D. Dobrew, Wrocław, s. 145-161.

Hvížd’ala K., 1981, České rozhovory ve světě, Köln.

Jedlička J., 2009, Okraj a střed, w: idem, České typy a jiné eseje, Praha, s. 75-80.

Jelinek E., 1998, Er nicht als er (zu, mit Robert Walser), Frankfurt am Main.

Kroutvor J., 1990, Potiže s dějinami. Eseje, Praha.

Masáková M., 2001, Komentář, w: K. Michal, Soubor díla, red. i posł. M. Masáková, Praha, s. 667-685.

Michal K., 2001a, Přemili sousedé, w: idem, Soubor dila, red. i posł. M. Masáková, Praha, s. 553-562.

Michal K., 2001b, My, občané melští, w: idem, Soubor díla, red. i posł. M. Masáková, Praha, s. 601-661.

Michal K., 2001c, Možnost volit, w: idem, Soubor dila, red. i posłowie M. Masáková, Praha, s. 662-665.

Štulcová M., 2005, Osudový exil. S Violou Fischerovou hovoři Magdalena Štulcová, „Revue Prostor” nr 67-68, s. 181-190.

Walser R., 2013, Mikrogramy, przeł. M. Łukasiewicz, Ł. Musiał, A. Żychliński, Kraków. Żychliński A., Musiał Ł., Łukasiewicz M., 2013, Posłowie, w: R. Walser, Mikrogramy, przeł. M. Łukasiewicz, Ł. Musiał, A. Żychliński, Kraków, s. 125-136. 